1977-12-01

\title{
Algal response to a thermal effluent : study of a power station on the Provo River, Utah, USA
}

Lorin E. Squires

Brigham Young University - Provo

Follow this and additional works at: https://scholarsarchive.byu.edu/etd

\section{BYU ScholarsArchive Citation}

Squires, Lorin E., "Algal response to a thermal effluent : study of a power station on the Provo River, Utah, USA" (1977). Theses and Dissertations. 7982.

https://scholarsarchive.byu.edu/etd/7982

This Dissertation is brought to you for free and open access by BYU ScholarsArchive. It has been accepted for inclusion in Theses and Dissertations by an authorized administrator of BYU ScholarsArchive. For more information, please contact ellen_amatangelo@byu.edu. 
AIGAL RESPONSE TO A THERMAL EEFLUENT:

STUDY OF A POWER STATION ON HHE

PROYO RIVER, UTAH, USA

A Mankscript of a Jourlial Articie

Presented to the

Deprartnent of Botany and Range Science

Brigharli Young University

\author{
In Partial Fulfillnent \\ of the Reguirements for the Degree \\ Doctor of Pliticosophy
}

by

L.orin F. Squires

Deccinber 1977 
ALGAL RESPONSE TO A THERMAL EFFIUENT:

STUDY DF A POWER STATION ON THE

PROVO RIVER, UTAH, USA

Lorin E. Squires

Department of Botany and Range Science

Brigham Young University

Provo, Utah, USA 84602

Key words: electric station, thermal effluent algae, diatoms, periphyton 
ABSTRACT

The effect of a thermal effluent on the attached algae of the Provo River, Utah, USA, was studied from 1975 to 1977. Data for macroscopic and microscopic algae were collected and ana?yzed. Diatoms, Cladophora glomerata, and Hydrurus foetidus dominated the flora. The thermal effluent significantly affected the algal flora in a section of river 100 to 135 meters long immediately below the discharge point. Cladophora growth was increased and Hydrurus was absent in this area. In addition, diatom production was often higher and diversity lower than in the rest of the river. Community structure was unique from all other adjacent areəs. Small temperature increases which occurred as effluent and river waters mixed farther downstream were apparently not as important to the algal flora as other environmental factors. 
AI.GAL RESPONSE TO A THERIMAL EFFLUENT:

STUDY OF A POWER STATION ON THE

PROVO RIVER, UTAH, USA

\section{INTRODUCTION}

Environmental pollution has become a major concern in recent years. Orie reason for this concern is the change it can create in the habitat of living organisms. Although natural environmental conditions are by no means constant, living organisms have developed adaptive mechanisms which enable them to cope with natural variability. However, poilution-instigated environmental changes frequently occur today "for which the species or community has inadequate information and thus is incapable of an appropriate response" (Cairns, 1972). As a result, the composition of species associations often changes under stress, causing some species to increase in prominence and others to decline or disappear. The agents which can cause such changes may be defined biologically as pollutants. Most pollutants are introduced into the environment directly or indirectly by man.

One environmental variable especially important: in ajuatic ecosystems is temperature. Man can affect water temperature indirectly through waterway manipulation, including ren:oval of forest canopies: reduction of stream flows, or creation of impoundments; and directly through introduction of thermal effluents into the water jystems (Warren, 1971). When such conditions affect living organisms, the potential exists for themal pollution. 
Currently, the major source of thermal pollution in both marine and fresh water systems is waste heat from the industrial use of water for cooling. The most common industrial solirce of pollution is the thermal-e?ectric power industry (Parker \& Krenkel, 1969) in which cooling water is used to absorb the heat produced from nuclear and fossil fuel steam-driven electric generators.

The extent to which thermal pollution affects auatic organisms has received considerable attention by researchers and managers in recent years. Much literature has accumulated reporting the results of field and laboratory studies on the responses of aquatic organisms to variations in water temperature (see Coutant: \& Pfuderer, 1974 and Coutant \& Talmage, 1975 for recent reviews). However, only a limited amount of information is avai?able concerning the effects of heated discharges from electric power plants on in situ algal communities (Patrick, 1974). Of the field studies reported, most involve large rivers, lakes or estuaries as receiving waters, and much of the emphasis has beer. on conditions which exist in the summer months when temperatures are highest. Thermal effluents in many rocations have been found to increase algal production, decrease the number of alga? species in the flora, and cause a shift from diatom to green and bluegreen algal associations (Patrick, 1969; Trembley, 1960; TVA, 1967a; Welch; 1969, Foerster, et a1., 1974). In other locations slight reductions in plankton or periphyton growth have been observed (Cairns, et al., 1972; Vadas, et a1., 1976), or the differerices between rormal and thermally affected waters have nor 
been significant (Patrick, 1969; Keller, ei al., 1973; TVA, 1967bj. A few studies have also included information on how heated effluents influence seasonai changes in algai communities, including reports on the effects of eliminating winter ice cover (Pidgaiko, et al., 1972; Hickman, 1974; Hickman \& Klarer, 1974, 1975; Klarer \& Hickman, 1975).

P.quatic research has revealed that while valid gerieralizations can cften bo made about aquatic ecosystems, each river, lake and estuary possesses a unique set of characteristics which results in unique responses to pollutants. With regard to thermal pollution, certain ecosystems have not been investigated. In addition, much is yet to be learned concerning what happens to community dynamics in aquatic systems when external heat sources cause abnormal water temperature fluctuations. Additional ecological data are certainly necessuiry to provice the information needed to formulate sound conclusions regarding the ecological impact of thermal pollution.

This paper reports a study of the effects of a thermal effluent from Utah Power and Light Company's Hale Generating Station on the attached algal community of the Provo River, a sinall fastflowing mountain river in north central Utah, USA. The algal study was part of an aquatic research project designed to determine the effects of the thermal effluent on aquatic biota in accordance with Section 316(a) of the Federal Water Pollution Control Act of 1972 (F.W.F.C.A., 1972).

The Provo River originates in the Uinta Mountains of Utah and flows approximately 103 kilometers $(\mathrm{km})$ through the north 
central part of tine state to Utah Lake. The river's water is generally of high quality and supports a wide diversity of aquatic life, including a good trout fishery. A large reservoir (Deer (reek Reservoir) on the river stores water for municipal and agricultural use in Utah and Salt Lake Valleys. Water released from the reservoir has changed the normal flow regime of the river. In addition, the lower reaches of the Provo River have undergone extensive management for man's use arid coritrol of the water. Water is diverted for irrigation, hydroelectric power generation, and cooling of steam-powered generators, causing water flow to vary greatly from one part of the river to another. The Hale Generating Station and a hydroelectric plant (Olmstead Flant) are located at the mouth of Provo Canyon where the Provo River enters Utah Valley after dissecting Utah's Wasatch Mouritain Ränge (Fig. i). Water velocities äre higin in this area becalise of a steep gradient and straight, narrow channel. The substrate is almost completely covered with stones, and the banks are heavily lined with willows and cottonwood trees. The Utah Division of Wildlife Resources (1970) has classified this section of the river as important to the fishing program of the state and county, and the Utah State Division of Health (1968) has said that the water should be protected against wastes or activities which will raise the temperature more than $2^{\circ} \mathrm{F}\left(! .1^{\circ} \mathrm{C}\right)$ or elevate the overal? temperature above $68^{\circ} \mathrm{F}\left(20^{\circ} \mathrm{C}\right)$.

The Hale Generating Station is a small coal-fired plant with a 47 megawatt maximum sutput. Cooiing water for the plant is diverted from the Frovo River at the Olmstead Diversion (Fig. 1) 
and is iransported by pipe to the 0lims tead Hydroelectric Plant. After leaving the Oimstead Plarit, the water is divided. Part of it flows in a canal to the adjacent Hale Generating Station, and the rest is returned to the river's natural channel (Fig. 2). Water flow in the canal normally ranges between 170 and 255 cubic meters per minute (100-150 cfs). Of this water, a constant 125 $\mathrm{cu} \mathrm{m} / \mathrm{min}$ (73.5 cfs) is cycled through the condensers of the Hale Station and then returned to the canal where it mixes with excess canal water. The increase in temperature of the water crossing the condensers ranges from 8.3 to $10^{\circ} \mathrm{C}$ during maximum output. However, during the winter months, the condenser water is often recirculated to prevent freezing of the intake screens. The temperature of the discharge can then be as high as $15^{\circ} \mathrm{C}$ above ambient, although the recirculating means that the volume of water thermally loaded is reduced. The actual daily discharge temperatures fluctuate according io power output of the generating station and diurnal temperature fluctuations of the incoming water.

From October thirough April, the thermal discharge is returned directly to the Provo River. From May to September, most of the waters are diverted directly to an irrigation canal and thus provide little thermal impact on the river itself. The 20-year averages of monthly flows for the Provo River in Utah Valley from 1955 to 1974 ranged from $1377 \mathrm{cu} \mathrm{m} / \mathrm{min}$ (810 cfs) in Jurie to $393 \mathrm{cu} \mathrm{m} / \mathrm{min}$ (231 cfs) in September for the period when the effluent was diverted for irrigation, and from $454 \mathrm{cu} \mathrm{m} / \mathrm{min}$ (267 cfs) in October to $853 \mathrm{cu} \mathrm{m/min} \mathrm{(502} \mathrm{cfs)} \mathrm{in} \mathrm{April} \mathrm{for} \mathrm{the}$ 
period when the thermai discharge was returned to the Provo River (Roberts, 1974). During this later period, the Hale Station used from 14 to 27 percent of the Provo River water. The thermal plume extended downstream in a narrow band along the west bank of the river, and the water mixed rapidly because of the swift, turbulent flow. Complete mixing occured within a $0.6 \mathrm{~km}$ distance, and the mixed water ranged between $0^{\circ}$ and $3^{\circ} \mathrm{C}$ above ambient.

Many factors influence the effect a thermal effluent has on the temperature regime of a receiving water. These factors include the temperature of both the effluent and the receiving water: the relative and absolute volumes of the effluent; the effects of current, wind, and mixing patterns; channel morphology; and air temperature. The coribination of these factors in the Provo River is favorable to the promotion of rapid heat assimilation, even though the therma? effluent, in terms of percentage of river flow and temperature rise across the conder!sers, is higher than those reported from power plants which are situated on larger rivers [i.e., 5.5 percent of the Connecticut River flow, with a $7.1^{\circ} \mathrm{C}$ rise in temperature (Foerster, et al., 1974); 4.7 percent of the Tennessee River flow, with a $5.6^{\circ} \mathrm{C}$ temperature rise (TVA, 1967b); S percent of the Green River, Kentucky, with a $5.6^{\circ} \mathrm{C}$ temperature rise (Welch, 1969); and an $8^{\circ} \mathrm{C}$ temperature rise in the Potomac River (Patrick, 1969).]

The algae growing in the Provo River are predominantly periphyton (algae which grow on the substrate). These algae are primary producers in the river and in addition provide habitat for many other aquatic organisms. Because periphyton are 
relatively immobile and because many species are sensitive to environmental conditions, they are good indicators of environmental conditions and changes. Therefore, they can provide significant information concerning the environmental impact of the effluent waters from the Hale Generating Station on the Provo River. The intent of the research performed in this study was to measure this impact.

The specific purposes of this study were: (1) to characterize the algal communities, (2) to identify community and production differences between the temperature-affected areas and the control regions: and (3) to determine the extent and impact of these differences.

\section{MATERIALS AND METHODS}

The study area extended upstream in the Provo River from the Hale Generating Station to the Olmstead Hydroelectric Plant tailrace and downstream approximately $0.6 \mathrm{~km}$ to where complete mixing and assimilation of the heat waste had occurred (Fig. 2). Sampling was done at 12 river transects established in the study area, two above and 10 below the thermal discharge. The transects were combined into eight temperature control or treatment zones based on temperature and mixing patterns in the river.

Control Zone 1 (Co-1) included the section of river upstream from the discharge point. Control Zone 2 (Co-2) included a section across the river and downstream from the discharge point. Although near the discharge point, Co-2 received no heated water because of horizontal stratification. Temperature 
Zone $1(\operatorname{Tr}-1)$ included the discharge channe? hereafter referred to as the outfall and an area in the river immediately below the discharge point where waste heat was maximum. This zone is also referred to as the Effluerit Area. Temperature Zones 2 through 6 $(\operatorname{Tr}-2--\operatorname{Tr}-6)$ were established at various stages of mixing downstream.

Data analyses were designed to investigate algal responses and community differences in these eight zones. However, the alga: community differences which actually occurred were often bettoin represented and more easily illustrated if the origina? zones were grouped into four major river areas. These areas included a Controi Area (C), which received no thermál input: (CO-1 and Co..2); an Effluent Area (E), which included the area of maximum therma 7 impact $(\mathrm{Tr}-1)$; Mixing Area $1(M-1)$, which included $\mathrm{Tr}-2$ ard $\mathrm{Tr}-3$; and Mixing Area $2(\mathrm{M}-2)$, which included $\operatorname{Tr}-4, \operatorname{Tr}-5$, ar:d $\operatorname{Tr}-6$.

\section{Field Procedures}

Algal periphyton was sampled between October 1975 and September 1976. Artificial samplers containing glass slides were attached to bricks and placed on the river bottom along the transects established in each temperature zone. The samplers were retrieved at four to six week intervals, and the slides were returned to the laboratory for quantitative analysis. Each slide was processed as a unit and will hereinafter be referred to as a stand. Currerit, depth, and temperature readings were taken on each collection date. Continuous temperature information was obtained 
from Ryan thermographs placed in strategic locations throughout the study area.

Percent cover estimates of the macroscopic algae on the river substrate were taken from February 1976 to August 1977. A viewing box with a glass bottom 30 by 35 centimeters $(\mathrm{cm})$ was used to view the river substrate, and estimates of the percent cover of each species were made using Daubenmire's (1968) cover classes.

\section{Laboratory Procedures}

Microscope slides with attached microscopic periphyton were treated as follows: The algae on one side of a slide were scraped with a razor blade and washed with distilled water into a labeled centrifuge tube. An estimate was made of the cover on the opposite side of the slide using a Zeiss RA microscope at 400 magnification. Cover ciass estimates were used, and averages were obtained for each species of algae, excluding diatoms.

After the microscope estimates, the second side of the slide was scraped and washed into the aforementioned centrifuge tube. The combined contents were centrifuged, and the wash water was replaced with five to ten milli?iters (mi) of concentrated nitric acid. The tube was placed into a beaker of boiling water until all the organic matter was oxidized. The sample was subsequently washed with distilled water by successive centrifugation and decanting until the sample was free of acid. The sample was then transferred to a calibrated tube and diluted to a known volume. After thorough mixing, an aliquot of sample was placed 
in a Palmer Counting slide (Palmer \& Malony, 1954), and the diatoms were counted. In most cases, examination of three ocular fields was enough to insure that 95 percent of the sample means were within \pm 10 percent of the true mean. The formula: $n=$ $\left((\bar{x})^{2 S}(0.7)\right)^{2}$ where $S=$ standard deviation, $\bar{x}=$ mean, and $n=$ field counts, was used to calculate the minimum number of field counts required. Counts obtained from two aliquots were averaged to obtain a count for the slide.

Permanent diatom slides were prepared from each sample by dryirg an aliquot of diatom frustules on a cover slip and then mounting the cover slip in Naphrax molintant on a microscope s?ide. The diatom species on each slide were identified and counted using a Zeiss RA microscope with Nomarski interference phase contrast accessories. Four hundred diatom frustuies were counted on each slide, and the relative percent density for each species was calculated from the counts. These percentage figures were multiplied by the Palmer siide counts to obtain the number of organisms of each species per square millimeter $\left(\mathrm{mm}^{2}\right)$ of substrate. Additional slides were scraped, and dry weight and ashfree weight were measured following standard methods (APHA, 1971).

Data Analysis

Diatom data were analyzed using an IBM 360 model 65 computer. The analyses included: (?) diversity index calculations on both individual sampies and means for each temperature zone to summarize community structure information, (2) cluster analysis of 
similarity indices to identify stand and species associations, and (3) discriminant analysis to determine what amount of discrimination existed between groups of stands on the ias is of environmental and biological variables.

The data obtained from estimating cover percent of nondiatoms on the microscope slides and the algal dry weight va?ues were compared using analysis of variance. The non-diatom results were also analyzed usirig cluster and discriminant techniques.

Cover estimates of macroscopic algae were compared from three of the temperature areas (Control Area, Effluent Area, and Mixing Area 1). The comparative and seasonal results for total cover and individual species cover were studied for differences and trends.

Diversity $(\bar{d})$ indices were calculated from the formula: $\bar{d}=-\sum_{T}^{S}(\mathrm{Ni} / \mathrm{N}) \log _{2}(\mathrm{Ni} / \mathrm{N})$ where $\mathrm{S}=$ number of species, $N=$ number of individuals in $\mathrm{S}$ species, and $\mathrm{Ni}=$ number of individuals in the ith species. This formula reduces the distortive effect of rare species on the overall index and is independent of sample size. It gives a number which is highest when the number of species is high and the number of individuals per species is evenly distributed, and lowest when many individuals are distributed in only a few species (Wilhm \& Doris, 1968).

Cluster analyses were performed by calculating a similarity index in percent from the formula: $\frac{\sum \min \left(X_{i}, Y_{i}\right)}{\sum \max \left(X_{i}, Y_{i}\right)}$ and then clustering the indices using unweighted pair-group clustering techniques (UPGMA) (Sneath \& Sokal, 1973). The UPGMA method computes the average similarity of each unit to the cluster, 
using arithmetic averages. It is wide?y used and has been found to introduce less distortion than other methods (Kaesler \& Cairns, 1972). The diatom data in numbers of ceils per $\mathrm{rm}$ on the microscope slide were clustered according to similarity of stands and also similarity of the species associations within the study area for each collection period.

Discriminant analyses were conducted using the Statistical Package for the Social Sciences (SPSS) computer progrâm (Klecka, 1975). This technique distinguishes statistically between two or more groups of stands on the basis of discriminating variables. The groups and variables are selected by the researcher. All variables measured can be used in the analysis (direct method), or a stepwise method can be used to reduce the number of variables to those which provide the best discriminating power among the groups. In this study, both the direct and the Wilks stepwise methods were used. The Wilks method lises the overall multivariate $F$ ratio to test for variable differences. It selects the variables independently for entry into the analysis based on the importance of their discriminating power.

The analysis procedure combines the discriminating variables to create discriminant functions designed to provide maximum separation among the groups previousty specified. The discriminant program determines the relative percentage of the total variation in the discriminating variabies which is accounted for in each function. It also determines the relative importance of each variable lised to create the discriminant functions. This 
information can be used to identify the variables having the greatest influence on the outcome of the analysis.

A graphic representation of the results of discriminant: analysis is possible if the discriminant functions are viewed as axes in geometric space. A plot of stands based on the two most important functions locates the stands in two-dimensional space in such a way that the relationships anong the groups can be visualized. Such a graphic repiesentation is especially important for assessing the amount of separation between one group zild another and the degree of group overlap.

The discriminant program provides a classification capability which serves two purposes. It has a predictive value and can be used to classify an unknown stand in one of the groups. It can also be used to test the adequacy of the previously derived discriminant functions. The stands which were used to determine the discriminant functions are given a predicted classification, and the predicted group is compared with the actual group to which the stand belongs. The percentage of correct classification is a measure of the success of the discrimination.

Discriminant analysis was performed on stands grouped according to temperature zones and on groups suggested by the cluster analysis. One set of analyses used environmental parameters as discrimiratory variables. A second set used the species counts in numbers of indiviauals per $\mathrm{mm}$ as the variables. Data for the study were processed and analyzed from five specific collection periods representing seasons of the year. 
These included Fall (October 4 to November 14, 1975), Fall-Winter (November 14 to January 7, 1976), Winter (January 7 to February 27 , 1976), Spring (Apri1 7 to May 10, 1976), and Summer (June 19 to July 30, 1976). Capitalization of the seasons hereafier in this report will refer to these specific coliection periods. The only exception was the macroscopic aigae data, which were taken monthly from February 3, 1976 to August 23, 1977.

\section{RESUI.TS AND DISCUSSION}

\section{Diversity Analysis}

The diatom communities throughout most of the study area were rich in species diversity during the Fall, Fall-Winter and Winter collection periods. However, in Spring species diversity de-. clirned (Fig. 3). This deciine extended into Summer and was caused by fewer total species and by the dominarice of Coccorieis placentula var. euglypta.

The only exception to this trend was in the Effluent firea where diversity values were significantly lower than in the rest of the river during the first three collection periods $(a=.01$ in Fail and Fall-Winter, $a=.05$ in Winter; Fig. 3). The communities in this area remained much the same throughout the year. Slides were always coated with heavy growths of Cocconeis placentula var. euglypta, and other species seldom occurred abundantly. One exception was Achrianthes minutissima, which occurred in appreciable numbers during Fall-Winter, Winter, and Spring. Generally, high diversity values (above 3 for the index used in this study; Wilhm \& Doris, 1968) have been related to 
clean water conditions and lower values represent various levels of pollution. However, Archibald (1972) has demonstrated that diatom diversity does not always follow this pattern and that diatom associations with low diversity can occur in clean water habitats.

Chemical and nutrient ievels of the Provo River changed little during this study. Even so, the river supported high diversity during cold weather months and low diversity during warm weather months. This seasonal change in community diversity is certainly related to environmental conditions, but parameter's which vary considerably with the season, such as ternperature, current, and radiation, are more important than water chemistry in determining this diversity.

The importance of the diversity index in this study lies in the comparison of $\bar{d}$ values between adjacent areas of the river within a given collection period. In Fall, Fall-Winter, and winter when diatom diversity was normally high, the thermal discharge altered the environment in the Effluent Area, creating a condition much like late spring and summer when diversity was low. During Spring and Summer when diatom diversity was naturäly low, the species associations in the Effluent Area were much like those in the rest of the river.

\section{Cluster Analysis}

When a collection of stands forms association patterns (clusters) which are related to each other at index values much lower than the average within-cluster reiationship values, there is evidence 
that some environmental or biological variable is creating disturbance and causing local segregation within the community. The similarity levels at which clusters form are relative. In a suboptimal environment such as occurred for diatom growth in the Provo River during Summer, species diversity is reduced to a few tolerant species. Consequently, interstand variabilit.y might be reduced and stand similarity be high (Fig. 4). Howevein, when species diversity is rich, population pressures and sensitivit.y to local microenvironmental variables are generally greater, resuiting in much lower natural similarity of stands. This occurred in the study area in Winter (Fig. 4).

Al1 of the cluster dendograms for the Provo River study area were similar to the dendogram for Spring (Fig. 5). Five to seven major ciusters consistently formed, uniting at leveis below 50 percent. Between 70 and 80 percent of the stands ciustered within a range of 30 percentage points (from 50 to 80 percent similarity). The only exception was the Summer dendogram. in Summer, the same basic pattern was evident, but all of the clusters formed above the 64 percent 1 evel.

The cluster patterns did provide evidence that certain variables caused the stands of diatoms to group into clusters, even though the patterns which developed were weak and varied from season to season. The stands from the Control zone ( $\mathrm{Co}-1)$ clustered welr in Fall and Spring and to a lesser extent in FallWinter. Many stands from $\mathrm{Tr}-5$ and $\mathrm{Tr}-6$ clustered together in Spring and to a lesser extent in Winter. Tr-4 data were only collected in Spring and Sumner. These stands clustered mostly 
with $\mathrm{Tr}-5$ and $\mathrm{Tr}-5$, although a few showed similarity to Co-1. $\mathrm{Tr}-2, \mathrm{Tr}-3$, and Co-2 stands showed a tendency to cluster together throughout the year. In addition to these trends, many clusters formed from stands scattered throughout the study area. The lack of consistency in observed cluster trends and the random manner in which many stands were interspersed throughout the dendograms suggest an overall homogeny in the study area with a weak tendency toward zonation on the basis of general river location.

The one notable exception to this weak zonation pattern occurred in the Effluent Area. Nearly all of the stands from this area throughout the entire study period were included in disinct clusters, which in turn were consistently different from other stands in the river (Fig. 4, 5).

in Winter, Effiluent stands showed considerable withinzone variability, even though they still were distinctly different from the rest of the river. The Hale Station was closed for cleaning and repair from the third through the fifth week of the Winter colonization period. Populations of Achnanthes minutissima, Achnarthes lanceolata, Gomphonema ol ivaceum, Diatcma vulgare, $\underline{\text { Navicula lanceolata, and Stephanodiscus astrae var. minutula }}$ which were present in Winter Effluent samples apparentiy became established during the shutdown and were only slowly displaced after the plant resumed operation. This high within-zone variability is attributed to disturbance created by abrupt environmental changes. It seems likely that this winter Effluent community represents a rebound toward a natural river community with the 
elinination of the abnormal thermal environment. The change furthermere suggests that while the thermal stress caused by the Hale Plant prevented many species from colonizing in appreciable numbers, it was not sufficient to rapidly eliminate them once they became established.

In Summer, although most of the Effluent was diverted for irrigation, a small amount of heated water was returned to the river. The temperature of this water in the Effluent Area was often $3^{\circ} \mathrm{C}$ above the temperature of the river. In Summer, the two stands collected directly from the outfall did not cluster with stands from the rest of the Effluent Area. The water in the outfall was shallow and more turbulent than in the river just below the discharge point (although the turbulence was reduced in Summer because of the small Hale Plant discharge returned to the Provo River). Also, the outfall was not as heavily shaded as the rest of the Effluent Area. During most of the year, the effect of the elevated water temperature in this area was great enough to mask the natural environmental differences, and ail the stands clustered together. However, in Summer, when the thermal impact was reduced, the natural dissimilarity of these two areas was reflected in the diatom flora. Thus, the magnitude of effect of a pollutant on a biological community may be expressed in the degree to which naturally occurring variation is eliminated by an overriding factor.

When the data were clustered based on species similarity rather than stand similarity, the results were less definitive than those from the stand clusters and appeared to have very 
little correiation with water temperature. In Fall, 17 of: the most abundant species in the river clustered together, and nine other frequently occurring species also formed a cluster. These species also occurred throughout the river but were limited in the effluent and, therefore, represented an important part of the diatom community of the river channel itself. In the Fall-Winter period, a similar cluster pattern included many of the same species, but in the Winter and Spring periods, only extremeiy low-level clustering occurred, and no patterr, was evident. The community formation in the Fall is due to autumn diatom bloom conditions which created high diversity and high production in the diatom flora throughout most of the study area.

The lack of temperature-related species clustering combined with the consistent stand clustering of the Effluent Area indicate that the effluent viaters affected the relative numbers of diatom species more than the actual presence or absence of specific taxa. That is, no species occurred in the Effluent Area that was not also prevalent in the rest of the river, and some of the species which did occur were either more or less abundant in the Effluent than at other locations. Furthermore, the thermal impact was localized in the Effluent Area. Downstream in the mixing waters, other environmental parameters masked the effects temperature may have had, and within-zone similarity was not sufficient to consistently separate these zones from the other zones in the river. 


\section{Discriminant Analysis}

Discriminant analysis was used to verify the environmental zonation in the study area. The parameters used as variables were: temperature, current, depth, substrate, and shading. Stands of data were first analyzed in groups corresponding to the initial eight temperature zones. The results suggested the desirability of grouping stands into the four larger areas: Control Area, Effluent Area, Mixing Area 1 and Mixing Area 2. With these groupings, the discriminant functions which were created provided significant and consistent separation among the four groups of stands throughout the year (Fig. 6). Classification results for these stands were also nigh (between 85 and 100 percent), thus indicating an environmental zonation within the study area and a high level of conformity of the individual stands of data to this zonation.

The water temperature variable was as expected the dominant discriminating variable throughout the year since the groupings were chosen in conformity with water temperature criteria. However, it is important to note that the other environmental parameters did not exert strong enougn influence to seriously affect the temperature-based classification. The amount of separation among temperature areas is related to the water temperature differential (Fig. 6). The largest differences occurred in the Effluent Area; and consequently, environmental stands from this area always grouped tightly together and showed more distinction than starids from the control and mixirg areas. 
Once the environmental zonation had been identified, the next step was to determine if the diatom populations also showed discriminating tendencies in the study area. Twenty-seven species which contributed to the algal flora throughout the year were chosen (Table 1). The data for these species, in numbers of individuals per $\mathrm{mm}^{2}$ of surface area for each stand, were submitted as variables for discriminant analy'sis. When the stands of diatoms were grouped according to the original eight temperature zones, the results were similar to those for the cluster analysis. Stands from the zones receiving initial impact from the thermally loaded water were distinctly separated from the other stands in a11 seasons except Summer. Occasionally, other temperature zones also were isolated, but usually there was considerable mixing and overlapping of the group boundaries of these zones. When the stands were grouped according to the four temperature areas used in the discriminant analysis of environmental parameters, the discriminant functions which were created also distinctly separated the Effluent Area from the other three areas during all seasons except Summer. The Control and Mixing Areas also separated from each other, al though overlapping of group boundaries was common.

The analysis was repeated using the four temperature groupings but transferring Contiol Zone 2 (Co-2) from the Control Area to Mixing Area 1, a grouping suggested by the cluster anal.ysis results. This manipulation reslitted in discriminant scores which produced tighter within-area groups and greater betweenarea separation than the previcus anz?ysis. During Fall, 
Fall-Winter, and Summer, the stands grouped very tightly in their respective areas (Fig. 7). In addition, the predicted classi fication of stands corresponded 100 percent with the actual stand classification. In Winter and Spring, the discriminant scores were more variable and the area boundaries showed some overlap. However, the integricy of the groupings was still good, and classification results were 91 percent for Winter and 92 percent for Spring.

The results of this anaiysis elucidate the trends indicated by the cluster ana?ysis. The Effluent Area is consistently the most distinctive in the river. The rest of the study area displays more homogeny in diatom distribution, although a diatom community zonation pattern does occur which corresponds to river location. In terms of temperature zones, the groupings are Co-1; Co-2, $\operatorname{Tr}-2$, and $\operatorname{Tr}-3$; and $\operatorname{Tr}-5, \operatorname{Tr}-6$ and to some extent $\operatorname{Tr}-4$. Co-2 and Tr-2 parallel each other in the river (Fig. 2) but have different temperature regimes since Co-2 receives none of the thermally heated water. The fact that Co-2 groups better with $\mathrm{Tr}-2$ than with Co-1 indicates that water temperature below the effluent is not as important as other existing environmental parameters in determining diatom distribution in this area.

The uniqueness of the Effluent Area partly may be attributed to river location, but the degree to which it segregates in the discriminant analysis indicates that a thermal impact also affects the diatom community in this area. Reasoning for this conclusion is based on: (1) the distinction of stands in the Effluent Area froin all other stancis throughout the year, this 
distinction occurring regardless of whether stands were grouped according to the eight temperature zones or the four temperature areas; (2) the lessening of this distinction in Summer when the temperature effect was reduced; and $(3)$ the fact that stands from temperature zones in the river grouped with adjacent zones to form three major diatom community groupings but that the Efflueni Area stands were markedly different even though the general habitat was similar to adjacent areas. Further support, for thermal impact was iridicated when discriminant analyses were performed on the basis of two groups, Effluent Area versus the rest of the river. The discriminant scores showed that the diatom community represented by the 27 selected species (Table 1) was discriminating between this area and all the rest of the study area.

\section{Macroscopic Algae}

The macroscopic algae and bryophytes, estimated in percent cover actually growing in place on the substrate, showed both seasonal and temperature-related distributions. The species encouritered ' were Cladophora glomerata, Hydrurus foetidus, Vaucheria sp., Audouinella violacea, Palmella mucosa, blue-green algae (including Chlorogloea microcystoides and two species of Phormidium which were most likely $\underline{\mathrm{P}}$. fragile and $\underline{\mathrm{P}}$. $\underline{\text { inundatum), }}$ and the moss Fontinalis duriaei. Of these species, cladophora glomerata was by far the most prevalent and ubiquitous in the river, and Cladophora glomerata and Hydrurus foetidus showed the most recognizabie response to water temperature. 
Although the overall yearly cycles were similar for the period of sampling, some difierences were caused chiefly by variations in water flow. The 1976-1977 water year was a drought yec.r for Utah, and the Provo River water flows were much lower than during the previous year. The decreased flow increased the impact of the effluent on the river and caused some changes in the macroscopic aigal flora. The main differences were an earlier deciine of algal growth in the spring of 1977 than occurred in 1976 and a higher percent cover in the Control Area in 1977 than occurred the previous year (Fig. 8). Another differerce was that Vaucheria sp. was not observed in the algal flora during tine high flow which occurred in the winter and spring months of 1976. However, it flourished in the Control and Effluent Areas during the winter and spring months of 1977 when river fiows were very low because of the drought.

The seasonal pattern for total cover showed increased production of algae beginning in September, high production during winter and early spring, and a decline through the sunmer. The total algal growth was higher in the Effluent Area than in any other area of the river throughout the sampling period (Fig. 8). The thermal!y enriched effluent appeared to have a stimulating effect on the Cladophora, Vaucheria, and moss growing in this area.

The growth of Cladophora glomerata largely determined the total cover of the river. This alga grew best during the winter and spring months and was most abundant in the effluent-affected witers. It died off significantly during the summer months in 
all areas of the river. The physical appearance of Cladophera reflected its vitality. In the Effluent Area it grew profusely from December to May, forming lush green streamers which covered the substrate. The size of the streamers decreased downstream, but growth was still profuse. From June through August most of the growth consisted of the stubby remnants of the previous growth, and viable, developing tufts of cladophora were rare. In the Control Area, winter growth consisied of dense, thick mats which were reduced in abundance in summer but still occurred in fast-flowing waters.

Hydrurus foetidus flourished ir fast-flowing, cold waters exclusively. It grew profusely throughout the Control Area and to a lesser extent in the mixing areas. It was absent from the Effluent Area except for a short period immediately after the gerierating station was shut down in Februarry 1976. Small amcunts of Hydrurus lingered in the Effluent Area after plant operation was resumed, indicating that once established, it can survive for a time under conditions that would prevent original colonization. This is similar to the diatom response mentioned earlier.

The results of the cover analysis during winter and spring months indicated a general trend toward increased growth of $\hat{c}$ Tadophora giomerata as temperature increased and a decrease in Hydrurus, foetidus growth along the same temperature gradient. This growth response trend is illustrated in Figure 9 for late winter and early spring of 1970 . The graphs in Figure 9 were made from cover estimates taken in the central part of the study area, downstream from the discharge point in Temperature Zores 
Co- $2, \operatorname{Tr}-\mathbf{i}$, and $\mathrm{Tr}-2$. The sections of river at the extreme end of the study area were not included in order to reduce interference from other environmental variables. However, the effect of temperature cannot be completely isolated, and the results illustrated on the graph are only presented to indicate the general trend. As indicated in Figure 9, small thermal inputs into the river are related to sharp increases in Cladophora glomerata growith, and additional temperature increases have a stimulating effect on Cladophora production. Furthermore, small temperature increases are associated with sharp declines in Hydrurus foetidus productivity, with the species disappearing from the fiora in waters above $7.5^{\circ} \mathrm{C}$. Another noteworthy point is that the temperature-cover percent curves produced in this period are similar even though the actual temperatures are different. This suggests that the growth response of both of these species to the thermal effluent is more relative than absolute during this period of the year.

Microscope Slide Non-diatom Algae and Dry Weight Analysis Sixteen species of non-diatom algae were found colonizing the microscope slides. A crustose green algal complex (Stigeoclonium sp. and Ulvella sp.) was a dominant constituent of this group both in terms of occurrence and percent composition throughout the year. Hydrurus foetidus was aiso a prominent colonizer in the winter months. Analysis of variance tests showed that with only one exception, differences in percent cover among temperature areas were statistically insignificant throughout the year, 
although the percent cover was usually lowest in the Effluent. Also, cluster and discriminant analyses failed to provide any information which would indicate environmental segregation of the non-diatom community.

The constancy of the IJvella-Stigeoclonium colonization in association with Cocconeis placentula var. euglypta parallels a situation reported by Butcher (1932) in which the U1vellaCocconeis association was the dominant alga? comrinunity in calcareous rivers of England. The abundance of the UlvellaStigeoclonium complex seemed to be associated with diatom production. In Fall and Fali-Winter periods when diatom growih was heavy and in other seasons on slides where diatom cover was high, the percent cover for Ulvella and Stigeoclonium was low. Cocconeis placentula var. euglypta cover was aiways high in the Effluerit Area, and the occurrence of green algae on the microscope slides in this area may be a secondary result of competition with Cocconeis.

The only trend suggested by the dry weight analysis of microscope slides was that biomass production was somewhat depressed in the central part of the study area (zones Co-2, $\mathrm{Tr}-1$, $\operatorname{Tr}-2$, and $(\mathrm{r}-3)$. However, dry weight vallies in these zories were only significantly different from the upper and lower zones during the Fall-Winter period.

The growth of non-diatom algae and dry weight production on the colonized microscope slides were apparently not significantly affected by the heated water from the effluent. They also 
appear to be weaker indicators of environmental variations in the river than are diatom populations.

\section{Diatom Production}

Diatom production figures (Table 2) were quite constant throughout the study area in the sumgner months when growing conditions were poor and only Cocconeis placentula var. euglypta was abundant. In other seasons, the totals fluctuated as the diatoms responded to local growing conditions. Significant diatom blooms occurred in Co-1 in Fall and Fall-Winter and in Tr-6 in Spring. Concurrent increases in production occurred in adjacent zones, but to a lesser degree. The figures for the outfall and $\mathrm{Tr}-1$ (Table 2) in Fall-Winter, Winter, and Spring suggest that the thermal discharge stimulated diatom production during this period. The increase in tota? production was largely due to greater numbers of Cocconeis placentula var. euglypta and Achnanthes minutissima.

Seasnnai flur,tuations showed high production in Fall and Fall-Winter followed by a sharp decline in Winter. With the exception of those from the Effluent Area, slides collected duririg Winter had a considerable amourit of uncolonized surface. Biatom production increased again in spring, àlthough the overall diversity was lower than in previous seasons. The low total for Co-? in Spring was possitily dise to increased abrasion damage Cäused by excevation and charinel clearing upstream coupled with spring rumoff conditions which periodically raised the silt load of the river. The ebrasion effects may have been more significant, 
in this area than downstream : where the water was deeper and diluted with water from the Hale Station discharge (Tr-2, Tr-3, and $T r-4)$ or protected by an irrigation diversion barricade (Tr-5 and $(r-6)$.

\section{The Effluent Area}

Annual temperatures in the Effluent Area ranged from $2^{\circ} \mathrm{C}$ in Febrliary 1976 when the Hale station was shut down to $24^{\circ} \mathrm{C}$ in August 1977 when a large portion of the effluent water was returned to the river because of the drought conditions which caussd low natural flows. Even in the discharge canal, summer temperatures above $27^{\circ} \mathrm{C}$ were not encountered. These maximum temperatures are below the $30-38^{\circ} \mathrm{C}$ temperature range which stimulates green and blue-green algal growth in other river systems (Patrick, 1974), and no summer increase in the growth of such algae was observed in the Effluent.

Most of the algal response to the Hale Station's thermal effluent occurred from late fall to early spring. Algal communities within the Effluent Area during this period were consistently distinct enough to demonstrate some thermal impact. The affected section of river included a stretch from 100 to 135 meters 1 ong on the west side of the river immediately below the outfail. Weekly mean water temperatures in this area for the 0ctober to May period ranged from $0^{\circ}$ to $10^{\circ} \mathrm{C}$ above ambient just bel the outfall and from $0^{\circ}$ to $3.5^{\circ} \mathrm{C}$ above ambient at a point 135 meters downs tream.

The algal stands 135 meters below the discharge displayed characteristics similar to stands in both the Effluent Area and 
in $\mathrm{Tr}-2$, and thus were transitioral between these two areas. For instance, the diatom stands in Fall-Winter from this area resembled those upstream near the discharge point. However, during all other seasons they were similar to stands in $\mathrm{Tr}-2$ and thus were grouped with this zone for most of the data presentation. The total cover and Cladophora glomerata cover 135 meters below the outfall were comparable to the upstream Eff? uent Area cover during winter months. During other seasons when foliage from overhanging cottonwood trees reduced insolation to the river substrate, both total and Cladophora cover were reduced. Cladophora in this "transitional zone" grew profusely and formed long streariers similar to the Cladophora upstream. Because of these similarities, this site was included with the Effluent Area for the analysis of macroscopic algae.

Audournella violacea was quite prevalent in this "transitional zone" during the winter and spring of 1976 and to a iesser extent in 1977. The only other place this alga occurred in abundance was immediately below the discharge point at the interface of the effluent waters and the river.

Although Cocconeis placentula var. euglypta occurred in the diatom flora throughout the study area, it. was especial?y abundant in the Effluent Area, both in absolute and relative density. The colonization slides were always thickly covered with this diatom, and it.s dominance in the diatom flora combined with the scarcity of other species contributed significartly to the isolation of the Effluent Area in the diatom analyses described above. 
The data presented in this paper indicate a modification of local ecology in the Effluent Area due to elevated temperature but do not explain the mechanics of how such modification occurs. However, it was apparent during the study that the extensive growth of Cladophora giomerata in Winter and Spring in the Effluent Area influenced diatom distribution. Most of the available epilithic substrate was colonized by Cladophora, which was in turn covered with the epiphytes Cocconeis, Achnanthes, and Gomphonema. These were also the most frequently encountered species on the slides from this area. Thus, it is possible that much of the unique diatom community siructure in the Effluent Area was influenced by colonization pressure, which would represent only a secondary temperature phenomenon.

\section{SUMMARY}

1. The Provo River, adjacent to the Utah Power and Light Hale Generating Station is fast flowing and has a rocky substrate which supports a prominent attached algal flora. Diatom species, Cladophora glomerata, and Hydrurus foetidus are major constituents of the flora. Cocconeis placentula var. euglypta is common throughout the year and dominates the diatom flora from late spring to early fall. Cladophora glomerata and Hydrurus foetidus are abundant in the flora from late fall to spring.

2. The flora of the study area displayed an overall similarity in specific composition but with a zonation tendency related to local environmental conditions in different sections of the river. 
3. An Effluent Area which extended 100 to 135 meters downstream from the thermal discharge point contained a flora significantly different from other areas of the river. The flora was characterized by very heavy Cladophora glomerata growth, a lack. of Hydrurus foetidus growth, high diatom production but low diversity, dominance of Cocconeis placentula var. euglypta throughout the year, and a diatom community composition which was consistently distinct from the rest of the river. Water temperature increases caused by the Hale Generating Station thermal discharge were highest in this area, and the uriqueness of the algal community is attributed to this thermal increase.

4. Effects from elevated temperature in sections of the river below the Effluent Area could not be distinctly isolated. Other environmental factors had interfering influences, and the changes in the argal communities did not correspond to temperature differences. Consequently, the temperature increase of $2-3^{\circ} \mathrm{C}$ which occurred in this area did not appear to significantly affect algal growth.

5. Statistical analyses using diversity, similarity, cluster, and discriminant techniques were useful in identifying diatom community patterns and assessing community responses to a thermal effluent.

ACKNOWLEDGMENTS

The study was funded in part by a grant from Utah Power and Light Company to the Center for Heaith and Envir onmental Studies, 
Brigham Young Inniversity. I thank Judith Grimes, Glen Squires, and Larry St. Clair for assisting with the sampling and laboratory analysis; Drs. Jack Brotherson and Selby Herrin for introducing me to the computer programs used in data analysis; Drs. Samuel Rushforth, Robert Winget, and Kimball Harper for providing advice and encouragement during the study; and Lorna Raty and Brent Ruggles for preparing the illustrations. I especially appreciate my wife, Carolyn M. Squires, who assisted with much of the sampling and was invaluable in editing and typing the manuscript. 


\section{REFERENCES}

American Public Health Association, American Water Works Association and Water Pollution Control Federation. 1971. Standard methods for the examination of water and wastewater. 13 ed. American Public Health Assoc., Washington, D. C. 874 pp.

Archibald, R.E.M. 1972. Diversity in some South African diatom associations and its relation to water quality. Water Res. (Gr. Britain) 6:1229-1238.

Butcher, R. W. 1932. Studies in the ecology of rivers:

II. the microflora of rivers with special reference to the algae of the riverbed. Ann. Bot. (Lond.) 46:813-861.

Câirns, J. 1972. Pollution related structurà and functional changes in aquatic communit ies with emphasis on freshwater algae and protozoa. Proc. Acac. Nat. Sci. Phila. 124(5): $79-127$.

Coutant, C. C. \&. Pfuderer, H. A. 1974. Thermal effects.

J. Water Pollut. Control Fed. 46(6):1476-1540.

Coutant, C. C. \& Talmage, S. S. 1975. Thermal effects. J. Water Pollut. Control Fed. 47(6):1656-1711.

Daubenmire, R. 1968. Plant Communities. Harper and Row, New York. 300 pp.

Federal Water Pollution Control Act. 1972. Title III-Standards and enforcement, thermal discharges section 316(a). 
Foerster, J. W., Trainor, F. R. \& Buck, J. D. 1974. Thermal effects on the Connecticut River: phycology and chemistry. J. Water Pollut. Control Fed. 46:2138-2152.

Hickman, M. 1974. Effects of the discharge of thermal effluent from a power station of Lake Wabamum, Alberta, Canada, The epipelic and epipsammic algal communities. Hydrobiologia 45:199-215.

Hickman, M. \& Klarer, D. M. 1974. The growth of some epiphytic algae in a lake receiving thermal effluent. Arch. Hydrobiologia $74(3): 403-426$.

Hickilan, M. \& Klarer, D. M. 1975. The effect of the discharge of thermal effluent from a power station on the primary productivity of an epiphytic algal community. Br. Phycoi. J. 10:81-91 .

Kaesler, R. L. \& Cairns, J. 1972. Ciuster analysis of data from limnological surveys of the upper Potomac River. Am. Midl. Nat. 88(1):56-67.

Keller, E. C., Jr., Becker, T., Bennett, H., Edens, D., Garrison, D., Janeczek, W. A., Keller, E., Keller, H., Kopyta, F., Kowal, N., Pisapia, R., Rankin, D., Shoupp, W. J., Silvester, J. A., Skinner, W. F., and Stein, A. 1973. Microsystems simulation of primary production in thermal and acid mine water loadings related to water use in the Monongahela River. Completion Report B-001-WVA Water Res. Institute, Appalachian Center, West Virginia Univ., Morgantown, West Va. 442 pp. 
Klarer, D. M. \& Hickman, M. 1975. The effect of thermal effluent upon the standing crop of a epiphyte algal community. Int. Rev. Gesamten Hydrobiol. 60(1):17-62. Klecka, W. R. 1975. Discriminant analysis. Pages 434-467 in N. H. Nie, C. H. Hull, J. G. Jenkins, K. Steinbrenner, D. H. Bent. SPSS statistical package for the social sciences. McGraw-Hil1 Co., New York.

Palmer, C. M. \& Maloney, T. E. 1954. A new counting slide for nannoplankton. Amer. Soc. of Limnol. and Oceanogr. Soc. publ. No. 21 .

Parker, F. L. \& Krenkel, P. A., eds. Engineering aspects of thermal pollution. Vanderbilt Univ. Press. Nashvilie, Tenr. $351 \mathrm{pp}$.

Patrick, R. 1974. Effects of abnormal temperatures on algai communities. Pages 335-349 in J. W. Gibbons and R. R. Sharitz eds. Thermal Ecology. conf. 730505, Technical Information Service, Atomic Eneray Commission, Oakridge, Tenn.

Patrick, R. 1969. Some effects of temperature on freshwater algae. Pages 161-271 in D. A. Krenkel and F. L. Parker, eds. Biological aspects of thermal pollution. Vanderbilt Univ. Press, Nashville, Tenn.

Pidgaiko, M. L., Grin, V. 0., Kititsina, L. A., Lenchina, L. G., Polivannaya, M. F., Sergeeva, 0. A., Vinogradskaya, T. A. 1972. Biological productivity of Kurakhov's Power Station cooling reservoir. Pages 478-491 in Z. Kajak and A. HillbrichtIlkowsaka, eds. Productivity Problems of Freshwaters. 
Proceedings of IBP-Unesco Symposium on Productivity Problems of Freshwaters, Kazimierz Dolny, Poland.

Roberts, S. H., Jr. 1974. Report of distribution of water supply entering Provo River. Unpublished report, Provo River water commission.

Sneath, P. H. A. \& Sokal, R. R. 1973. Numerical taxonomy.

W. H. Treeman and Co., San Francisco. 573 pp.

Tennessee Valley Authority. 1967a. Thermal and biological

stidies in the vicinity of Colbert Steam Plant. TVA Division $0:$ Heält h and Säfety, Water Quai ity Branch, Chattanooga, Tenn. Tennessee Valley Authority. 196?b. Thermal biological studies in vicinity of Widow's Creek Steam Plant. TVA Division of Health and Safety, Water Quality Branch, Chattanooga, Tenn.

Trembley, F. J. 1960. Research project on effects of condenser discharge water on aquatic life. Lehigh Univ. Institute of Research Progress Report 1956-1959, Bethlehem, Pa.

Trembley, F. J. 1965. Effects of cooling water from steamelectric power plants on stream biota. Pages 334-345 in Biological problems in water pollution. U. S. Department of Health, Education, and Welfare, 999w-25, Superintendent of Documents, U. S. Government Printing Office, Washington, D.C. Utah Division of Wildlife Resources. 1970. Utah fishing waters inventory and classification, review draft. Utah State Division of Health. 1968. Code of waste disposal regulation part II: standards of quality for waters of the state. 
Vadas, R. L., Kesler, M. \& Rusanowski, P. C. 1976. Influence of thermal loading on the ecology of intertidal algae. Pages 202-212 in G. W. Esch and R. W. MacFarlane, eds. ERDA Symposium Series, Conf-750425, Augusta, Ga. Warren, C. F. 1971. Biology and water pollution control. W. B. Saunders Co., Philadelphia, Penn. 434 pp.

Welch, E. B. 1969. Discussion of ecological changes of applied significance induced by the discharge of heated waters. Pages 58-68 in F. L. Parker and P. A. Krenkel, eds. Engineering aspects of thermal pollution. Vanderbilt Univ. Press, Nashville, Tenn.

Wilhmi, J. L. \& Doris, T. C. 1968. Biological parameters for water quality criteria. Bioscience 18(6):477-481. 
Table 1. Twenty seven of the most common diatom species in the Provo River study area. These species were used as variables in discriminant analysis, the results of which are illustrated in Fig. 7.

Achnanthes lanceolata (Bréb.) Grun.

Achnanthes lanceolata var. dubia Grun.

Achnanthes minutissima Kütz.

Amphora perpusilla (Grun.) Grun.

Cocconeis pediculus Ehr.

Cocconeis placentula var. euglypta (Ehr.) $\mathrm{Cl}$.

Cocconeis placentula var. lineata (Ehr.) v. Heurck

Cymbella sinuata Greg.

Cymbella ventricosa Kütz.

Diatoma tenue var. elongatum Lyngb.

Diatoma vulgare Bory

Fragilaria vaucheriae (Kütz.) Peters

Gomphonema olivaceum (Lyngb.) Kütz.

Gomphonema parvulum (Kütz.) V. Huerck

Melosira varians $\mathrm{Ag}$.

Navicula arvensis Hust.

Navicula cryptocephala var. exilis (Kütz.) Cirun.

Navicula cryptocephala var. veneta (Kütz.) Rabh.

Navicula lanceolata (Ag.) Kütz.

Navicula tripunctata (0.F. Müll.) Bory

Nitzschia dissipata (Kütz.) Grun.

Nitzschia frustulum (Kütz.) Grun. 
Nitzschia linearis (W. Smith) Frun.

Nitzschia palea (Kütz.) W. Smith

Rhoicosphenia curvata (Kütz.) Grun.

Stephanodiscus astrea var. minutula (Kütz.) Grun.

Synedra ulna (Nitzsch.) Einr. 


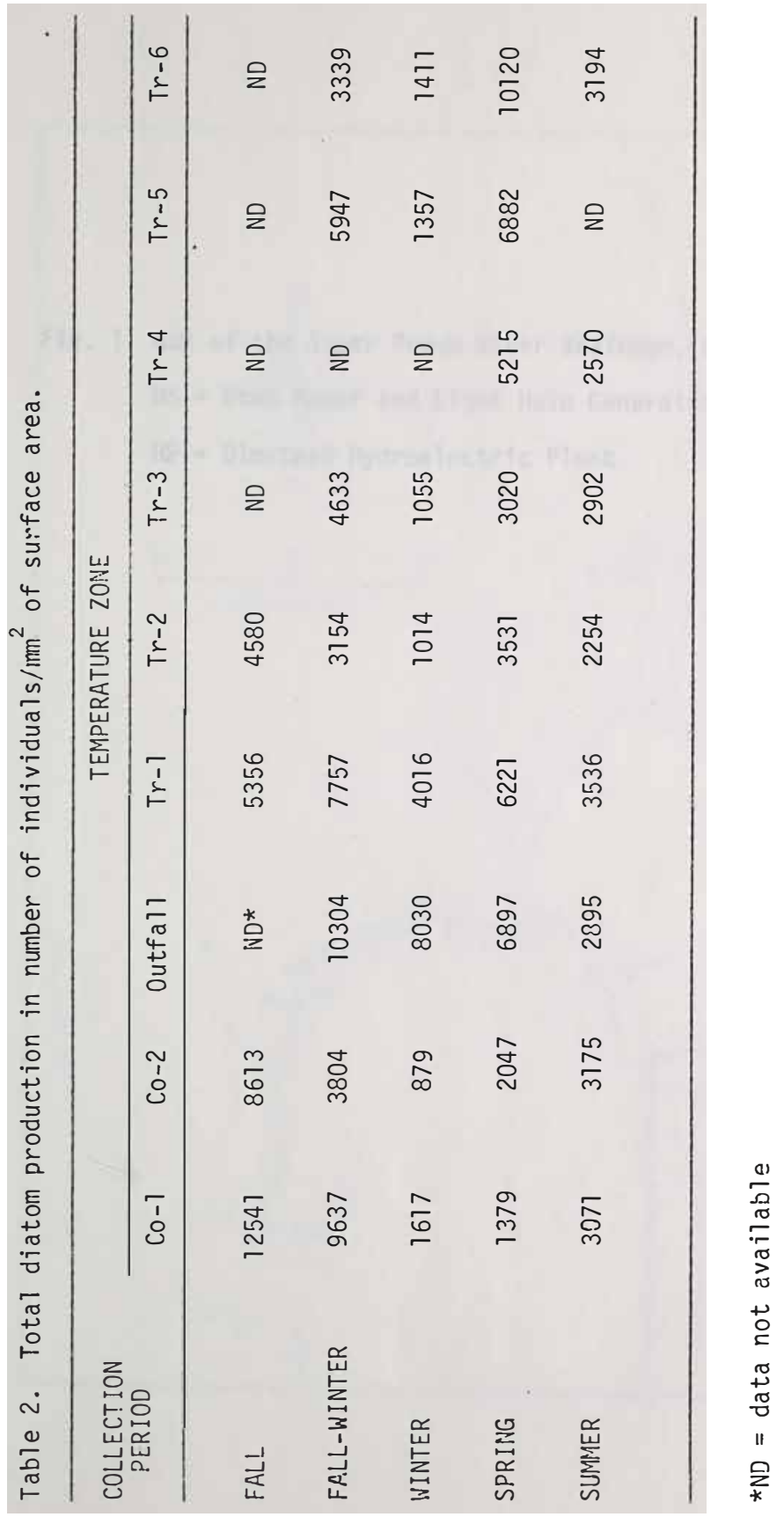


Fig. 1. Map of the lower Provo River drainage, Utah. HS = Utah Power and Light Hale Generating Station, $H P=01 m s t e a d$ Hydroelectric Plant. 


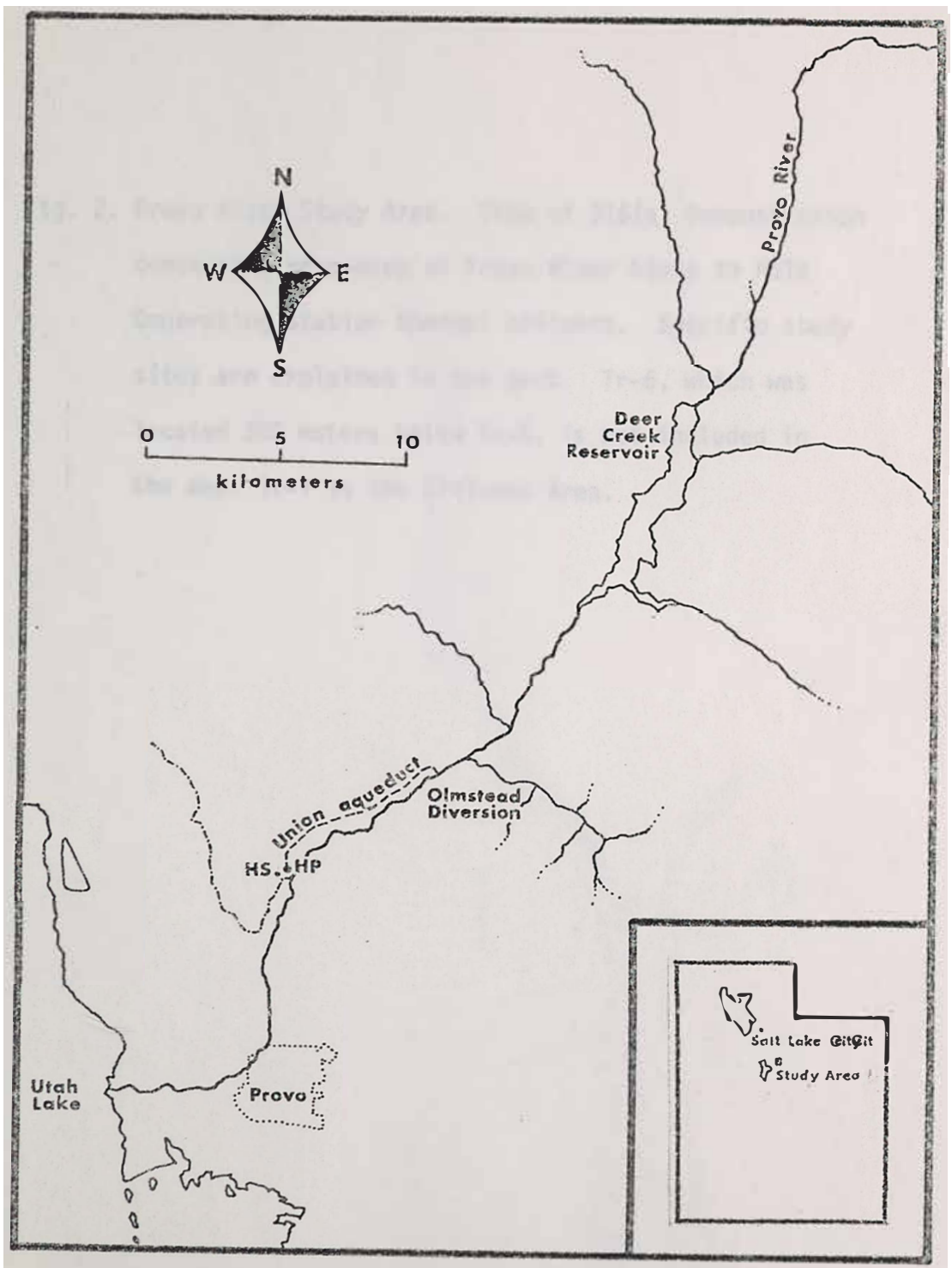


Fig. 2. Provo River Study Area. Site of 316(a) Demonstration concerning responses of Provo River biota to Hale Generating Station thermal effluent. Specific study sites are explained in the texi. $\operatorname{Tr}-6$, which was located 300 meters below Tr..5, is not included in the map. Tr-1 is the Effluent Area. 


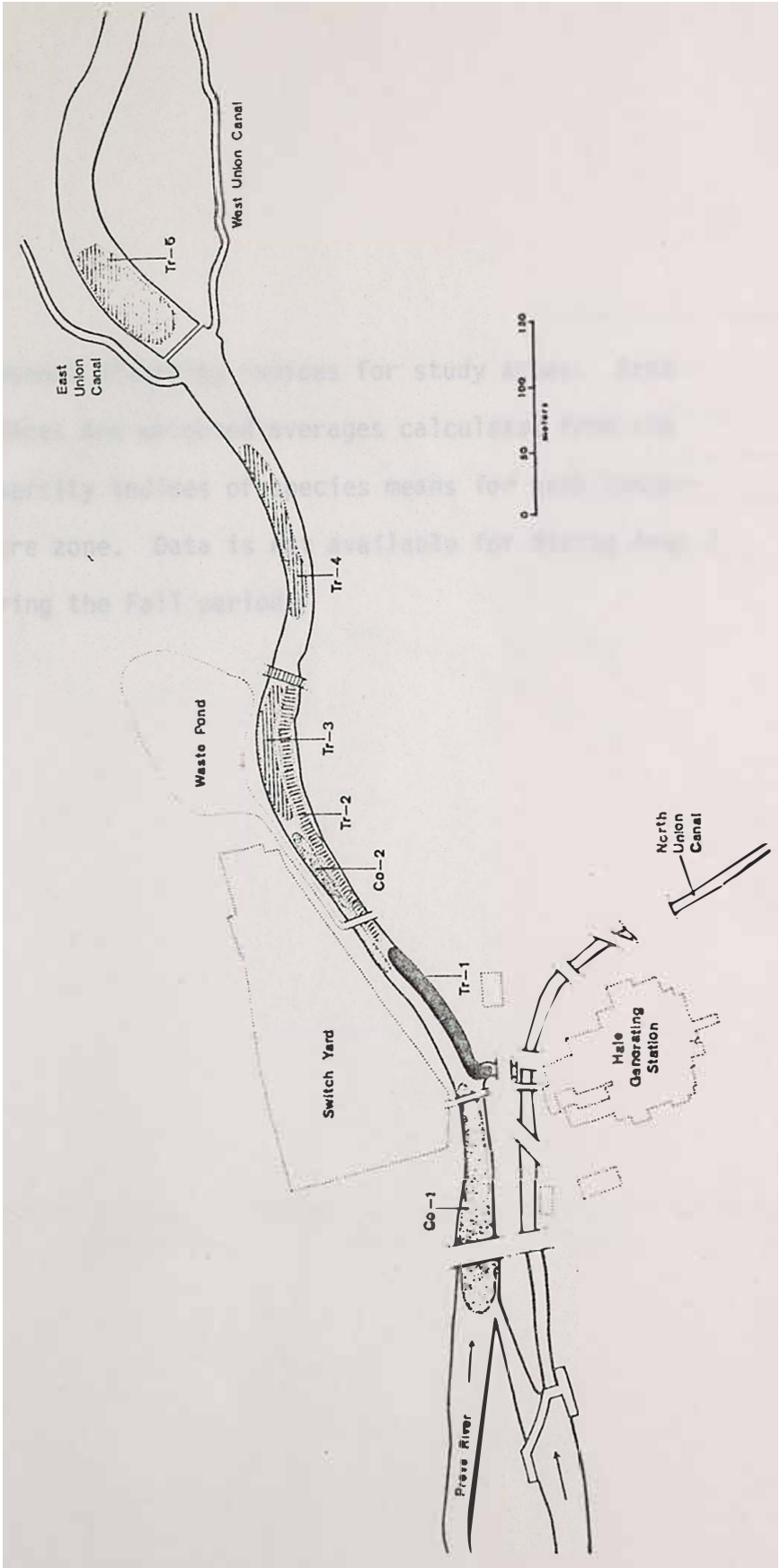


Fig. 3. Seasonal diversity indices for study areas. Area indices are weighted averages calculated from the diversity indices of species means for each temperature zone. Data is not available for Mixing Area 2 during the Fall period. 


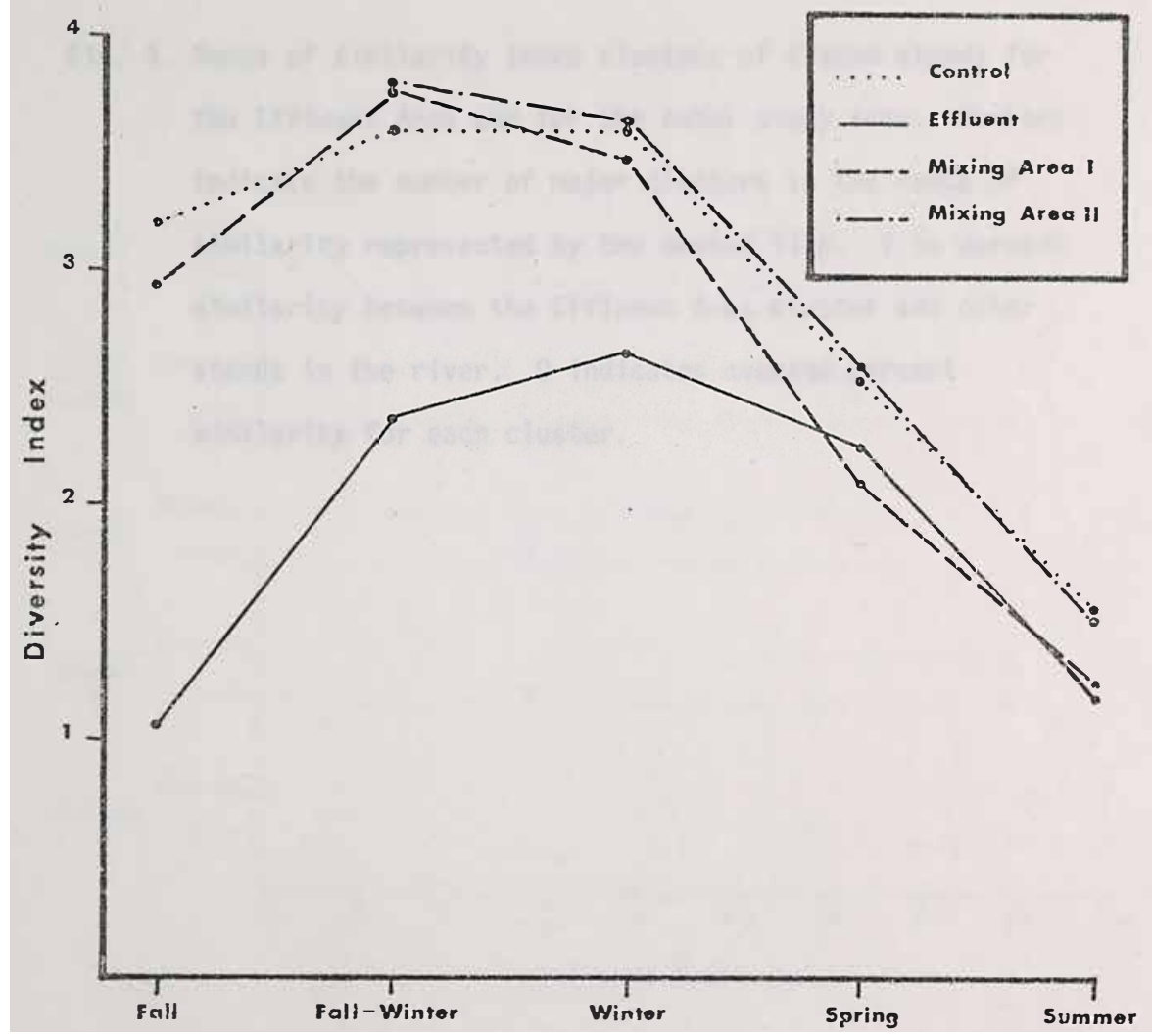


Fig. 4. Range of similarity index clusters of diatom stands for the Effluent Area and for the total study area. Numbers indicate the number of major clusters in the range of similarity represented by the dashed line. $V$ is percent similarity between the Effluent Area cluster and other stands in the river. 0 indicates average percent similarity for each cluster. 


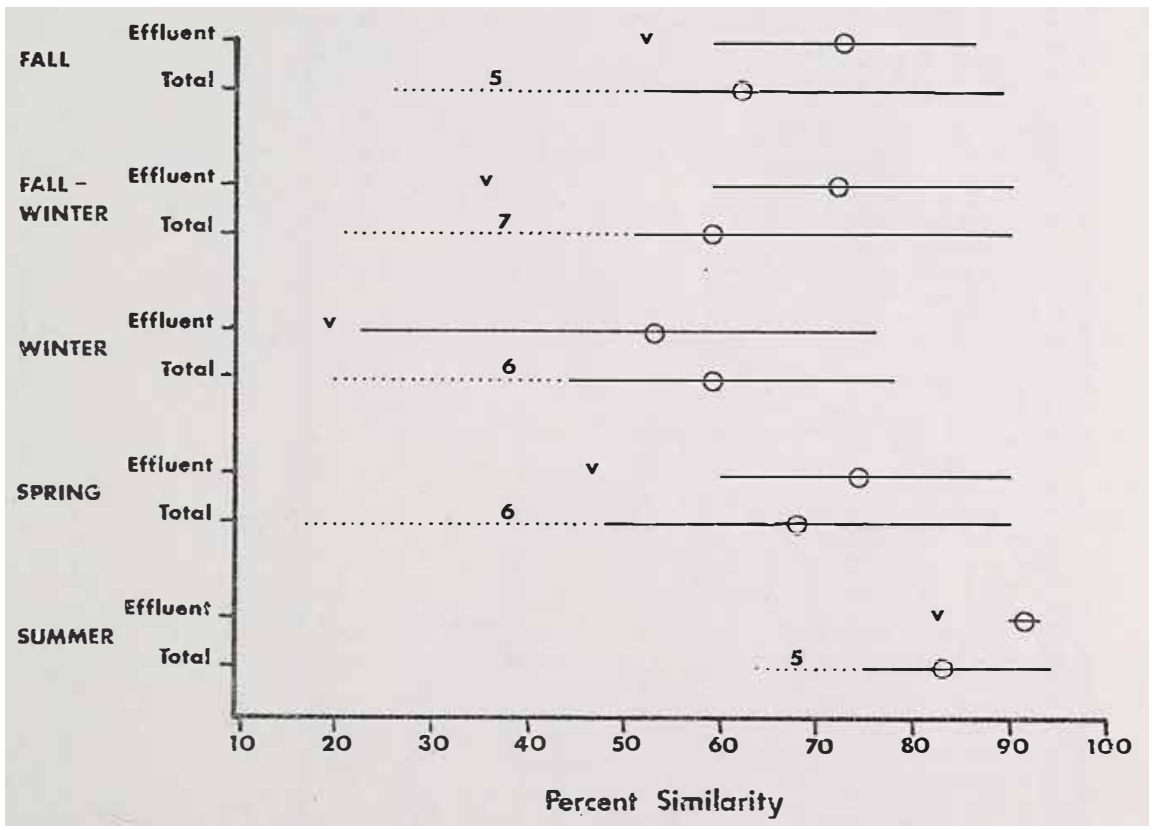


Fig. 5. Cluster dendogram showing similarities of stands of diatoms in the Provo River during Spring 1976. 


\section{Percent Similarity}

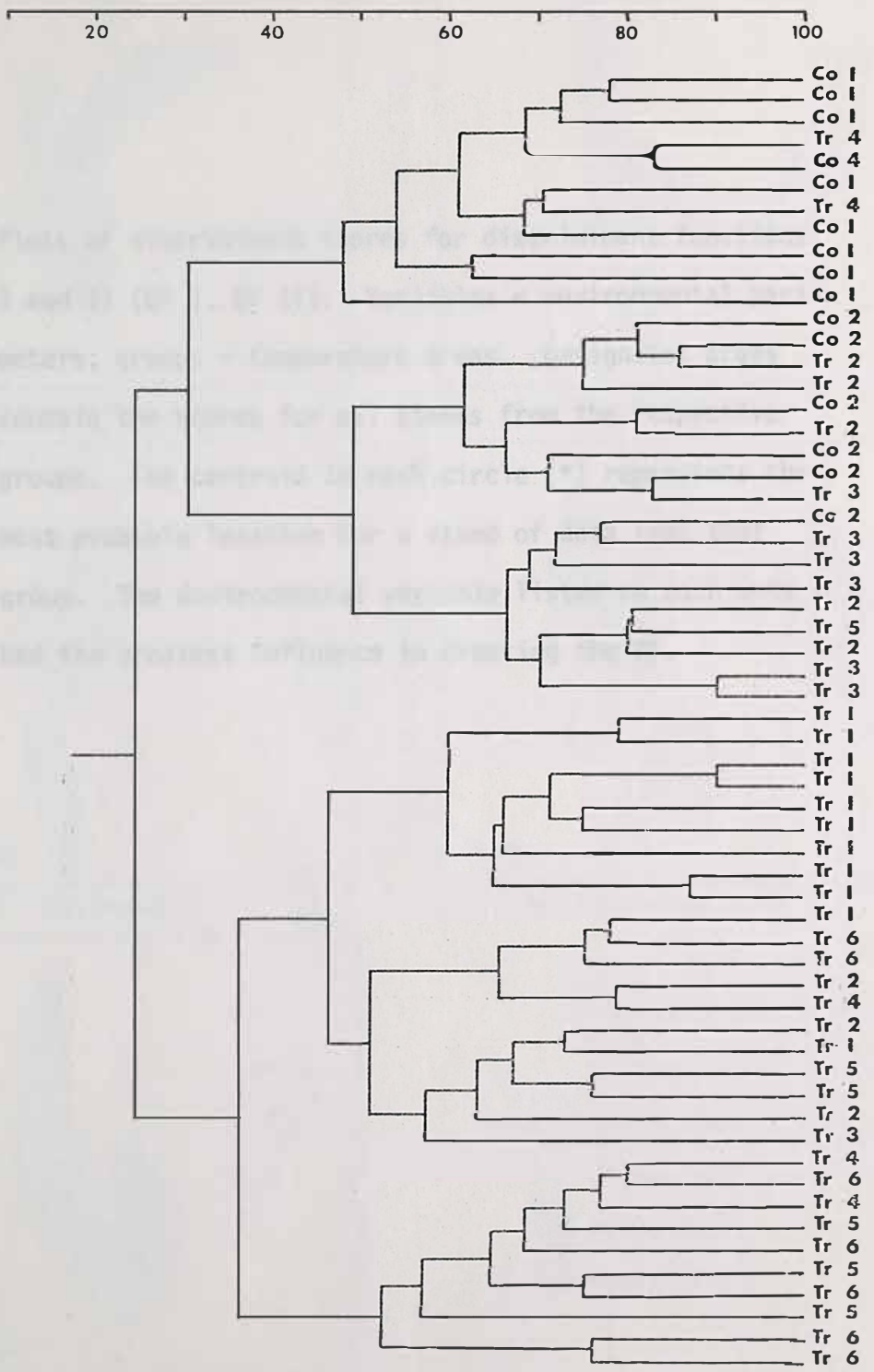


Fig. 6. Plots of discriminant scores for discriminant functions I and II (DF I, DF II). Variables = environmental parameters; groups $=$ temperature areas. Designated areas contain the scores for all stands from the respective groups. The centroid in each circle $(*)$ represents the most probable location for a stand of data from that group. The environmental variable listed on each axis had the greatest influence in creating the DF. 

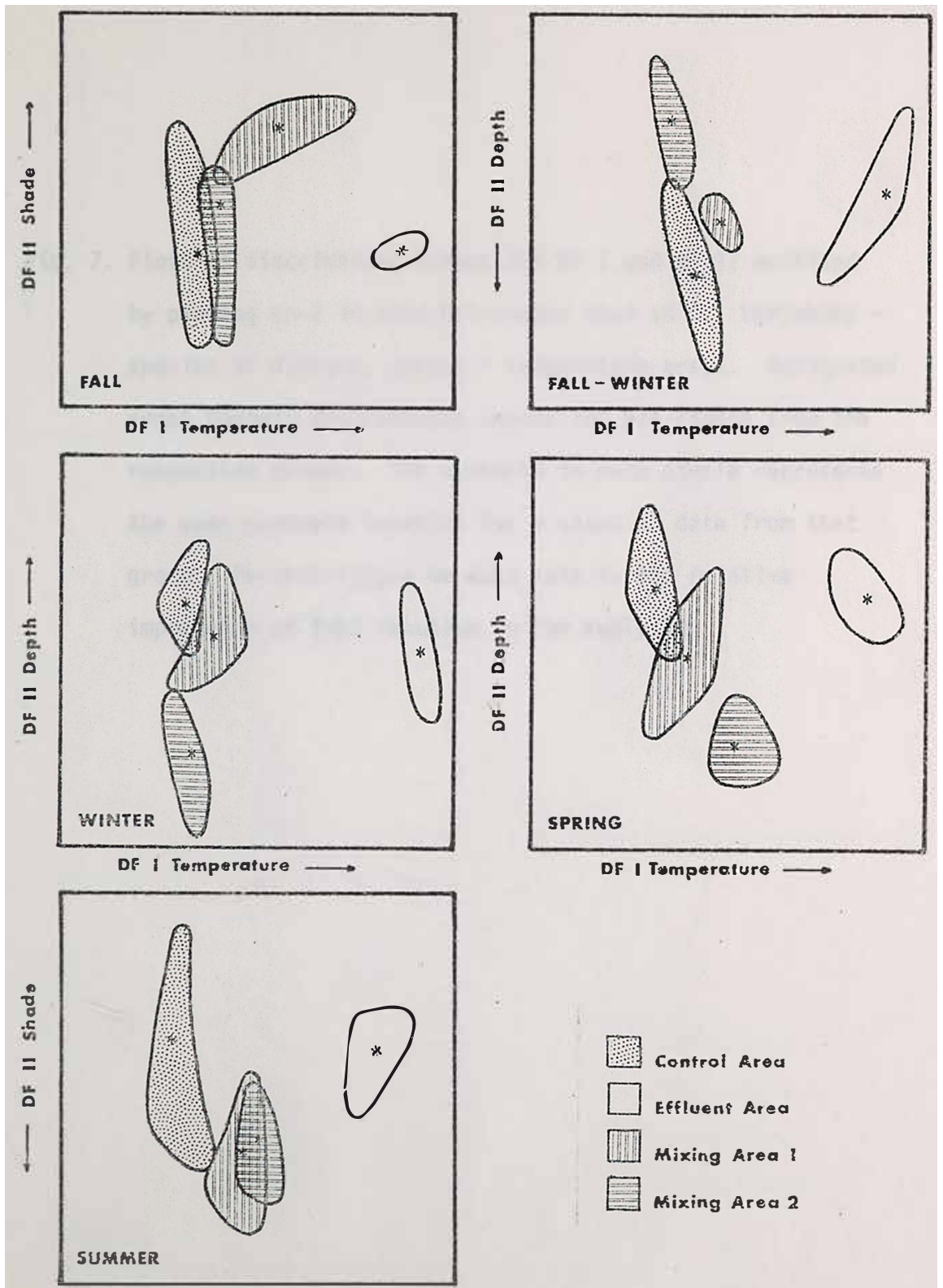

DF | Temperature

. Control Area Efflueni Area Mixing Area? Nixing Area 2 
Fig. 7. Plots of discriminant scores for DF I and DF II modified by placing Co-2 in area $M-1$ rather than in C. Variables $=$ species of diatoms; groups $=$ lemperature areas. Designated areas contain discriminant scoires for i:11 stands from the respective groups. The centroid in each circle represenis the most probable location for a stand of data from that group. Percent figure on each axis is the relative importance of that function in the analysis. 

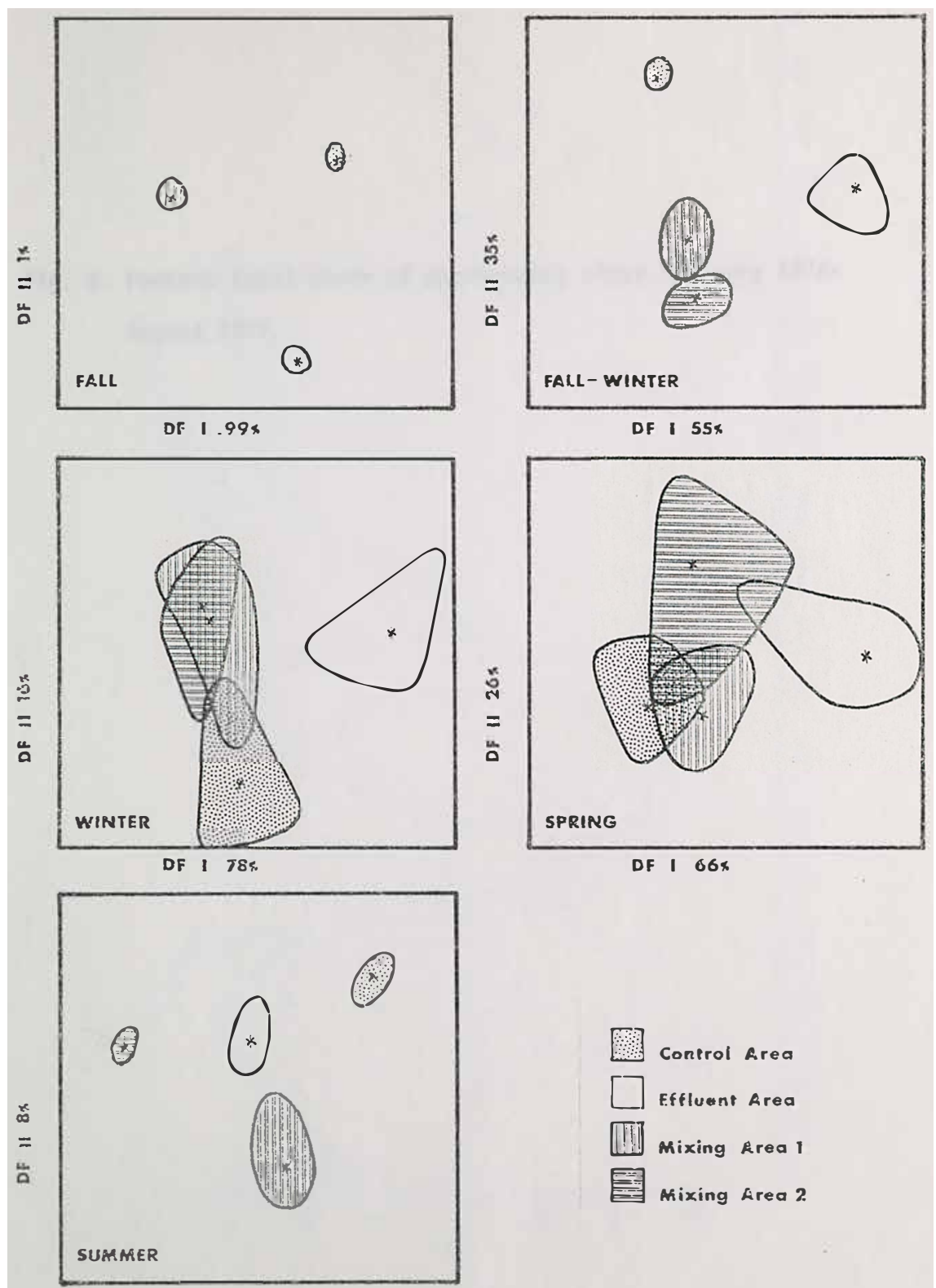
Fig. 8. Percent total cover of macroscopic algae February 1976August 1977. 


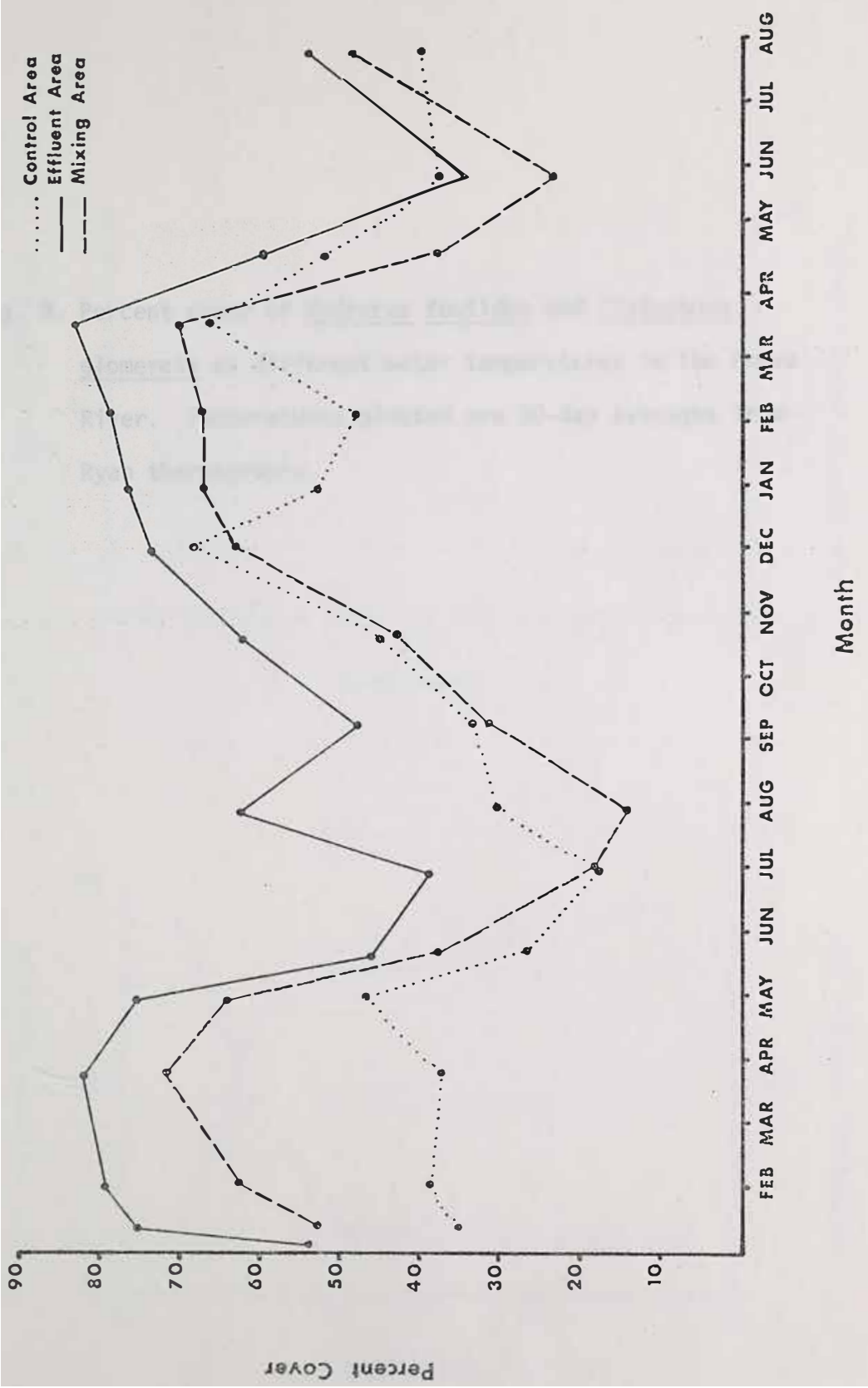


Fig. 9. Percent cover of Hydrurus foetidus and Cladophora glomerata at different water temperatures in the Provo River. Temperatures plotted are 30-day averages from Ryan thermographs. 

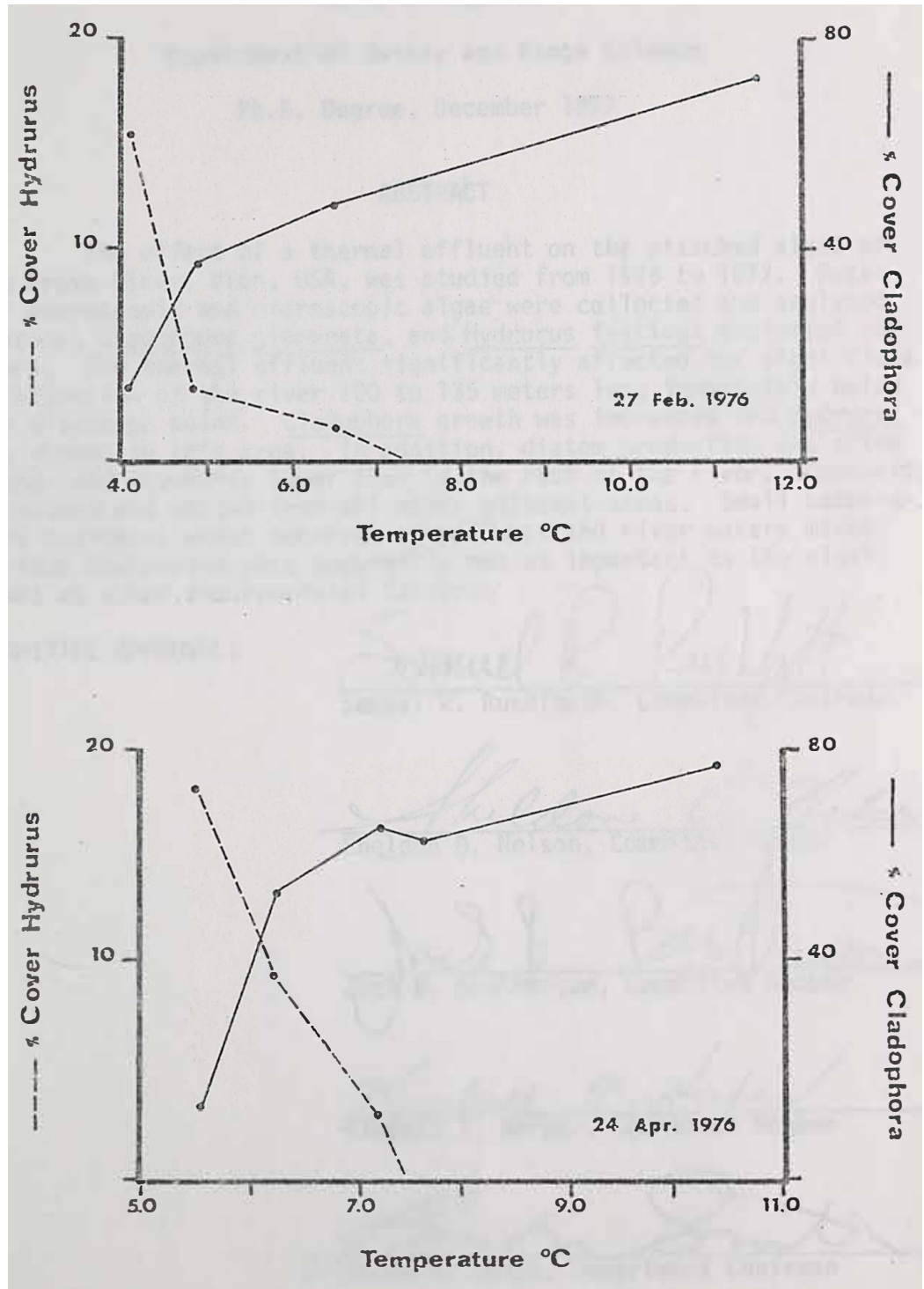